\title{
Si-PSA Tape with the Addition of Dolomite
}

\author{
Adrian Krzysztof Antosik* and Zbigniew Czech \\ Institute of Organic Chemical Technology, West Pomeranian University of Technology Szczecin, Poland
}

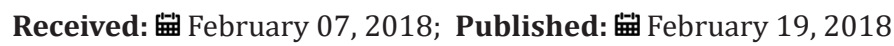

*Corresponding author: Adrian Krzysztof Antosik, Institute of Organic Chemical Technology, West Pomeranian University of Technology Szczecin, Poland, E mail: adriankrzysztofantosik@gmail.com

\begin{abstract}
It is well known that tapes on the silicone pressure-sensitive adhesives base are high quality products used for special applications. Due to the excellent performance characteristics such as high adhesion, cohesion and tack, while high chemical and environmental conditions resistance, the choice of the layer protecting the adhesive film is a big problem. Due to this, expensive fluoridated films are used as protective layers. In order to reduce costs, a suitable bending of the protective layer was introduced (limitations of the contact surface of the adhesive film with a protective layer) which reduces the protection of the adhesive film. The introduction of dolomite particles into the adhesive film is intended to facilitate the removal of the protective layer, while maintaining the level of protection at the level of expensive films.
\end{abstract}

Keywords: Silicone pressure sensitive ahesives; Easy peel; Dolomite

\section{Introduction}

Self-adhesive materials have been known since time immemorial. The first documented use of self-adhesive materials dates back to 6000 years BC in Egyptian civilization. A specific group of self-adhesive materials are pressure-sensitive adhesives (PSA - were in wide use since the late $19^{\text {th }}$ century, starting with medical tapes and dressings), which have the only self-adhesive properties at room temperature. There are many criteria for the division of pressure-sensitive adhesives. The pressure sensitive adhesive market includes a number of polymeric raw materials. There are used natural rubber, various types of synthetic rubber, such as styrene-butadiene and-ethylene co-polymers, polyvinyl ether, polyurethane, acrylic, silicones and etylenevinyl acetate-copolymers. However, basic pressure-sensitive adhesive formulations are acrylics, rubbers and silicones [1-3]. Silicone pressure-sensitive adhesives are widely used in pressure-sensitive tapes and labels when application conditions or the nature of substrate surfaces surpass the performance boundaries of organicbased PSAs. A combination of the unique properties of silicones, such as high $\mathrm{Si-O}-\mathrm{Si}$ backbone flexibility, low intermolecular interactions, low surface tension, excellent thermal stability and high UV transparency, often explains why silicone PSAs have superior performance at high- and low-temperature extremes, excellent electrical properties, chemical resistance and outstanding weathering resistance compared to organic PSAs. They are inert and very hydrophobic but still have reasonable moisture permeability.
It is well known that tapes on the silicone pressure-sensitive adhesives base are high quality products used for special applications. Due to the excellent performance characteristics such as high adhesion, cohesion and tack, while high chemical and environmental conditions resistance, the choice of the layer protecting the adhesive film is a big problem. Due to this, expensive fluoridated films are used as protective layers. In order to reduce costs, a suitable bending of the protective layer was introduced (limitations of the contact surface of the adhesive film with a protective layer) which reduces the protection of the adhesive film. The introduction of dolomite particles into the adhesive film is intended to facilitate the removal of the protective layer, while maintaining the level of protection at the level of expensive films [4-8]. In this paper commercial silicone adhesives and dolomite will be used as a component to obtained pressure-sensitive adhesives composition using to prepared self-adhesives tape with easy removal protective layer. In the available literature there are no reports about tape based on silicone PSA where easy-peel protective layer was obtained by used mineral filler.

\section{Material and Methods}

In work commercial silicone adhesive was used (acronym: PSA 529), which was product of Dow Corning (USA). Dichlorobenzoyl peroxide (DClBPO) was used as a cross linking agent. Peroxide was product of Peroxid-Chemie (Germany). Dolomite (acronym: Dolgran 
300), product of Jasnogórskie Kopalnie Surowców Mineralnych (Poland) was used as a filler with specific fragmentation. Silicone pressure-sensitive adhesive was mixed with cross linking agent to obtain homogeneous composition containing 50wt. \% polymer (2.5wt. \% on a base of polymer content DClBPO). Then, Dolgran 300 was added respect from the resulting composition 5, 10, 15, 25 or $35 \%$ wt. calculated on the dry weight of the silicon polymer and mixed to obtained homogeneous composition. Subsequently, composition was coated with coat speed of $5 \mathrm{~cm} / \mathrm{s}$ on polyester film $(36 \mu \mathrm{m})$, and dried for $10 \mathrm{~min}$ at $110{ }^{\circ} \mathrm{C}$ in drying canal. Thus obtained adhesive film was protected with polyester film $(50 \mu \mathrm{m})$. Obtained tapes were used for further tests, i.e. adhesion, tack and cohesion measured. Peel adhesion, tack, cohesion of silicone pressure-sensitive adhesives of PSA was measured using Zwick-Roell Z1 machine (Germany) and machine designed at the Laboratory for Adhesives and Self-Adhesive Materials of the West Pomeranian University of Technology Szczecin according to international standard Association des Fabricants Europeens de Rubans Auto-Adhesifs and Fédération International edes Fabricants et Transformate ursd'adhesifs et thermo-collants sur-papiers etautres support respectively AFERA 4015, AFERA 4001 and FINAT

Table 2: Impact of the additive dolomite on properties of PSA 529 with $2.5 \%$ wt. DClBPO.

\begin{tabular}{|c|c|c|c|c|}
\hline Content of dolomite [\% wt.] & Adhesion to steel [N/25mm] & Tack [N] & Cohesion [h] & Easy peel \\
\hline 5 & 18.3 & 5.8 & $>72$ & medium peel \\
\hline 10 & 15.7 & 5.0 & $>72$ & medium peel \\
\hline 15 & 14.5 & 1.8 & 1.3 & easy peel \\
\hline 25 & 3.8 & 0.5 & 3 & easy peel \\
\hline 35 & 2.3 & easy peel \\
\hline
\end{tabular}

\section{Conclusion}

Novel silicone pressure-sensitive adhesives tapes with easy peel protective layer have been obtained. In order to get the effect easy peel mineral filler (dolomite) was used in composition. Generally additive filler increased effect easy peel with decreased basic properties of PSA as adhesion, tack and cohesion. Best balance between basic properties of adhesives and easy peel protective layer exhibit composition PSA 529 with $15 \%$ wt. dolomite, where drastic reduction tack properties with a slight reduction in adhesion and leave cohesion at the same level allowed get the desired effect. It is generally accepted that one-sided adhesive tape must meet the basic properties (adhesion $>10 \mathrm{~N} / 25 \mathrm{~mm}$; tack $>8 \mathrm{~N} / 25 \mathrm{~mm}$; cohesion $>72$ hours) [12]. In novel PSA tape two from three basic conditions are done what suggest that tape can be used in industry but not for every application.

\section{References}

1. Czech Z, Kowalczyk A, Świderska J (2011) Pressure-sensitive adhesives for medical applications. Wide Spectra of Quality Control 17: 309-332.

2. Czech Z (2002) Sieciowanie samoprzylepnych poliakrylanowych wodnych klejów dyspersyjnych. Polimery 47: 234-241.
- FTM 8 [9-11]. The easy peel was measured organoleptic and it was a compared test.

\section{Results and Discussion}

Basic information about composition PSA 529 cross linking by $2.5 \%$ wt. DClBPO was collected in (Table 1) [12] to have opportunity of compared reference to physically modified compositions with the dolomite.

Table 1: Basic properties of PSA 529 with $2.5 \%$ wt. DClBPO.

\begin{tabular}{|c|c|c|c|}
\hline Adhesion to steel [N/25mm] & 15.7 & Tack [N] & 8.3 \\
\hline Cohesion [h] & $>72$ & Easy peel & hard peel \\
\hline
\end{tabular}

Influence of content dolomite on adhesion, tack, cohesion and easy peel properties of PSA 529 with $2.5 \%$ wt. DCIBPO were collected in (Table 2). With the addition of filler, a decrease adhesion, tack, and cohesion properties was noted. Decreasing value of basic properties it improves the detachment of the protective layer. Because of the basic properties and balance between them and the ease of detachment of the overt layer from the adhesive film, the composition containing $15 \%$ wt. dolomite shows the best properties.
3. Z Czech, A Kowalczyk, L Shao, XQ Cheng, S Quan, YP Bai (2013) Novel acrylic pressure-sensitive adhesive (PSA) containing silver particles. Journal of Adhesion Science and Technology 27: 1446-1454.

4. SB Lin, LD Durfee, RA Ekeland, J McVie GK (2007) Schalau: Recent advances in silicone pressure-sensitive adhesives. Journal of Adhesion Science and Technology 21(7): 605-623.

5. Z Czech, R Kurzawa (2007) Acrylic pressure-sensitive adhesive for transdermal drug delivery systems. Journal of Applied Polymer Science 106: $443-446$

6. GL Anderson, SD Stanley, GL Young, RA Brown, KB Evans, et al. (2010) The effects of silicone contamination on bond performance of various bond systems. The Hournal of Adhesion 86: 1159-1177.

7. S Mecham, A Sentman, M Sambasivam (2010) Amphiphilic silicone copolymers for pressure siensitive adhesive applications. Journal of Applied Polymer Science 116: 3265-3270.

8. G Tolia, SK Li (2012) Study of drug releas and tablet characteristics of silicone adhesive matrix tablets. European Journal of Pharmaceutics and Biopharmaceutics 82(3): 518-525.

9. Antosik AK, Ragańska P, Czech Z (2014) Termiczne sieciowanie samoprzylepnych klejów silikonowych nadtelenkami organicznymi. Polimery 59: 792-797.

10. Antosik AK, Czech Z (2015) Wpływilości barwnika na fizyczne właściwości silikonowych klejów samoprzylepnych. Przemysł Chemiczny 94: 41-42. 
11. Antosik AK, Czech Z (2017) Acrylic-silicone pressure-sensitive adhesives. Organic and Medicinal Chemistry 4: 1-3.
12. Antosik AK, Bednarczyk P, Czech Z (2015) Jednostronnie klejące taśmy na bazie samoprzylepnych klejów silikonowych-dobór najlepszej kompozycji. Chemik 69: 95-97.
(C) Commons Attribution 4.0 License

To Submit Your Article Click Here: Submit Article

DOI: 10.32474/AOICS.2018.01.000121

\section{AOICS}

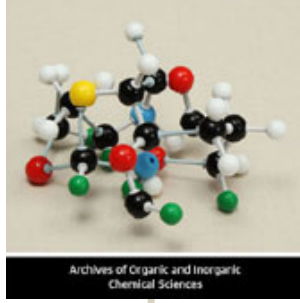

Archives of Organic and Inorganic Chemical Sciences

Assets of Publishing with us

- Global archiving of articles

- Immediate, unrestricted online access

- Rigorous Peer Review Process

- Authors Retain Copyrights

- Unique DOI for all articles 